\title{
Azoarcus anaerobius sp. nov., a resorcinol- degrading, strictly anaerobic, denitrifying bacterium
}

\author{
Nina Springer, ${ }^{1}$ Wolfgang Ludwig, ${ }^{1}$ Bodo Philipp ${ }^{2}$ and Bernhard Schink ${ }^{2}$
}

Author for correspondence: Bernhard Schink. Tel: +49753188 2140. Fax: +497531882966 e-mail: bernhard.schink@uni-konstanz.de

\author{
${ }^{1}$ Lehrstuhl für \\ Mikrobiologie der \\ Technischen Universität \\ München, Arcisstr. 16, \\ D-80290 München, Germany \\ 2 Fakultăt für Biologie, \\ Universität Konstanz, \\ Postfach 5560, D-78434 \\ Konstanz, Germany
}

\begin{abstract}
A strictly anaerobic, nitrate-reducing bacterium, strain LuFRes1, was isolated using resorcinol as sole source of carbon and energy. The strain reduced nitrate to dinitrogen gas and was not able to use oxygen as an alternative electron acceptor. Cells were catalase-negative but superoxide-dismutase-positive. Resorcinol was completely oxidized to $\mathrm{CO}_{2}$. $16 \mathrm{~S}$ rRNA sequence analysis revealed a high similarity with sequences of Azoarcus evansii and Azoarcus tolulyticus. Strain LuFRes $1^{\top}$ ( = DSM 12081') is described as a new species of the genus Azoarcus, Azoarcus anaerobius.
\end{abstract}

Keywords: Azoarcus anaerobius sp. nov., resorcinol-degrading bacterium

\section{INTRODUCTION}

Degradation of aromatic compounds has been studied in much detail in the recent past. Whereas most aromatic compounds are degraded by the benzoylCoA pathway (2), other aromatics are degraded via resorcinol (1,3-dihydroxybenzene) or phloroglucinol (1,3,5-trihydroxybenzene) as key intermediates (8). Fermenting bacteria reduce resorcinol to dihydroresorcinol (1,3-dioxocyclohexane) before the ring is cleaved hydrolytically $(6,13)$. Nitrate-reducing bacteria use a different pathway for resorcinol degradation which does not include primary reduction $(3,6)$.

In experiments for enrichment of resorcinol-degrading, nitrate-reducing bacteria, a strictly anaerobic, denitrifying bacterium was isolated which was unable to use oxygen as an alternative electron acceptor (3). In the present study, this organism, strain LuFRes $1^{\mathrm{T}}$, is described as the type strain of a new species, Azoarcus anaerobius, on the basis of $16 \mathrm{~S}$ rRNA sequence comparisons.

\section{METHODS}

A pure culture of strain LuFRes $1^{\mathrm{T}}\left(\mathrm{DSM} 12081^{\mathrm{T}}\right)$ was taken from the laboratory collection. The strain has been deposited with DSMZ (Deutsche Sammlung von Mikroorganismen und Zellkulturen, Braunschweig, Germany) under the reference number indicated. Strain LuFRes $1^{\mathrm{T}}$ was originally

The EMBL accession number for the sequence reported in this paper is Y14701. isolated from anoxic sewage sludge under strictly anoxic conditions (3).

The strain was cultivated in an oxygen-free, bicarbonatebuffered medium $(9,15)$ which contained trace element solution SL10 (16), selenite tungstate solution (16) and seven-vitamin solution (15) under a $\mathrm{N}_{2} / \mathrm{CO}_{2}(80 / 20)$ atmosphere. Details of cultivation and characterization are given in the original description (3). Ammonium-free medium was prepared without addition of ammonium chloride. This medium contained less than $0.05 \mathrm{mM}$ ammonium ions.

In vitro amplification and direct sequencing of $16 \mathrm{~S}$ rRNA encoding DNA fragments was done as previously described (10). The new 16S rRNA sequence was fitted into an alignment of about 8000 homologous full and partial primary structures available in public databases (7) using the respective automated tools of the ARB software package (12). Distance-matrix, maximum-parsimony and maximum-likelihood methods were applied as implemented in the ARB software package. Different data sets that varied with respect to included outgroup reference organisms (sequences) as well as alignment positions were analysed.

\section{RESULTS AND DISCUSSION}

The physiological properties of strain LuFRes $1^{\mathrm{T}}$ have been documented in detail before (3); the taxonomically relevant points are summarized in the species description at the end of this section. Since nitrogen fixation is an important property of members of the genus Azoarcus, this ability was also studied in the present strain. Strain LuFRes $1^{\mathrm{T}}$ could be transferred in ammonium-free medium for more than ten generations; however, this was only in the presence of 
Table 1. Overall 16S rRNA sequence similarities of strain LuFRes $1^{\top}$ and selected relatives of the $\beta$-subclass of the Proteobacteria. The range of sequence similarity is given for strain LuFRes $1^{\top}$ and various strains of $A$. evansii and $A$. tolulyticus. In all other cases, the mean similarity value is shown for strain LuFRes $1^{\top}$ and the reference species. The following species were studied (accession nos given in parentheses): 1, A. evansiilA. tolulyticus (L33687-L33692, U44853 and X77679); 2, A. indigens (L15531); 3, OS-ac-16 (U46748); 4, Thauera selenatis (X68491); 5, Thauera aromatica (X77118); 6, Zoogloea ramigera ATCC 19544 (X74913); and 7, Rhodocyclus tenuis (D16209).

\begin{tabular}{|c|c|c|c|c|c|c|c|c|}
\hline \multirow[t]{2}{*}{ Organism } & \multirow[t]{2}{*}{ Accession no. } & \multicolumn{7}{|c|}{ Similarity (\%) } \\
\hline & & 1 & 2 & 3 & 4 & 5 & 6 & 7 \\
\hline LuFRes $^{T}$ & Y14701 & $96 \cdot 1-97 \cdot 1$ & $95 \cdot 0$ & $93 \cdot 8$ & $93 \cdot 8$ & $94 \cdot 2$ & $92 \cdot 7$ & $90 \cdot 7$ \\
\hline A. evansii/A. tolulyticus & $\begin{array}{l}\text { L33687-L33692, } \\
\text { U44853, X77679 }\end{array}$ & & $95 \cdot 3$ & $93 \cdot 7$ & $93 \cdot 6$ & $94 \cdot 0$ & $92 \cdot 7$ & $90 \cdot 7$ \\
\hline A. indigens & L15531 & & & $95 \cdot 0$ & $94 \cdot 2$ & $94 \cdot 6$ & $92 \cdot 4$ & $90 \cdot 1$ \\
\hline OS-ac-16 & $\mathrm{U} 46748$ & & & & $93 \cdot 4$ & $94 \cdot 3$ & $91 \cdot 2$ & $90 \cdot 2$ \\
\hline Thauera selenatis & X68491 & & & & & $97 \cdot 7$ & $91 \cdot 7$ & $90 \cdot 8$ \\
\hline Thauera aromatica & $\mathrm{X} 77118$ & & & & & & $92 \cdot 7$ & $90 \cdot 4$ \\
\hline Zoogloea ramigera ATCC 19544 & X74913 & & & & & & & $91 \cdot 3$ \\
\hline
\end{tabular}

nitrate. No acetylene-reducing activity was found in these cultures. Cultures grown with $\mathrm{N}_{2} \mathrm{O}$ as electron acceptor required the addition of ammonium chloride as nitrogen source. It is concluded that this strain does not express nitrogenase activity but can use nitrate as a nitrogen source through assimilatory nitrate reduction.

16S rRNA encoding DNA from strain LuFRes $1^{\mathrm{T}}$ was amplified in vitro and directly sequenced. A comparative database analysis revealed highest sequence similarity $(96 \cdot 1-97 \cdot 1 \%$; Table 1) with strains of Azoarcus evansii (1) and Azoarcus tolulyticus (17). However, strain LuFRes $1^{\mathrm{T}}$ is clearly separated from this cluster as indicated by remarkably higher intracluster values (98.1\% and higher). Strain LuFRes ${ }^{\mathrm{T}}$, together with the other Azoarcus and Thauera species as well as the isolate OS-ac-16, represents a phylogenetic subgroup of the $\beta$-subclass of the Proteobacteria.

According to the $16 \mathrm{~S}$ rRNA sequence data, strain LuFRes $1^{\mathrm{T}}$ should be classified as a new species of the genus Azoarcus. So far, the genus comprises four validly described species: Azoarcus communis (4), $A$. evansii (1), Azoarcus indigens (5) and $A$. tolulyticus (17), which are represented by $16 \mathrm{~S}$ rRNA sequence data in public databases. Strains of $A$. evansii and $A$. tolulyticus are closely related. Overall 16S rRNA sequence similarity among these strains is $98.1 \%$ and higher. The sequence data do not provide sufficient information for unambiguous assignment of the strains to two different species and their current taxonomy needs revision. In some cases, the overall 16S rRNA similarity is higher for strains of different species than for strains of the same species. $A$. indigens is separated from this cluster by sequence similarities of 95.1-95.4\%. Unfortunately, in the case of $A$. communis, only partial sequences are available so far
(4). The similarities of these partial sequences and the homologous parts of the 16S rRNA primary structures of the other Azoarcus species are in the range $95 \cdot 1-$ $95.4 \%$ which do not indicate a close relationship between $A$. communis and any other species.

The closest relatives of strain LuFRes ${ }^{\mathrm{T}}$ are $A$. evansii and $A$. tolulyticus (Fig. 1). The separate status of strain LuFRes $1^{\mathrm{T}}$ is indicated by $16 \mathrm{~S}$ rRNA sequence similarity values of $96 \cdot 1-97 \cdot 1 \%$ (Table 1 ) with the members of the $A$. evansii/A. tolulyticus group, which are lower than the corresponding intragroup values $(98 \cdot 1 \%$ and higher; Table 1). Currently, the definition of a bacterial species is mainly based on the $70 \%$ criterion of genomic DNA similarity obtained by DNA-DNA hybridization (14). It is well-known that comparative $16 \mathrm{~S}$ rRNA sequence analysis usually does not provide differentiating information at the strain level and often cannot be used even for species differentiation. The correlation of genomic DNA and rRNA similarities has been evaluated by Stackebrandt \& Goebel (11). These authors described a level of rRNA sequence similarity of $97 \%$ and higher, at or above which DNA-DNA reassociation studies are a superior method. In the case of strain LuFRes $1^{\mathrm{T}}$ and the $A$. evansii/ $A$. tolulyticus cluster, rRNA similarity values at or below this level justify the rRNA-based description of a new species of the genus Azoarcus although this strain does not fix nitrogen as most other members of this genus do.

\section{Description of Azoarcus anaerobius sp. nov.}

Azoarcus anaerobius (an.a.e.ro'bi.us. Gr. pref. an not; Gr. n. aer air; Gr. n. bios life; N.L. adj. anaerobius not living in air, anaerobic).

Rod-shaped bacterium, $2 \cdot 7-3.3 \times 1.5 \mu \mathrm{m}$ in size, motile, Gram-negative, catalase-negative, superoxide- 


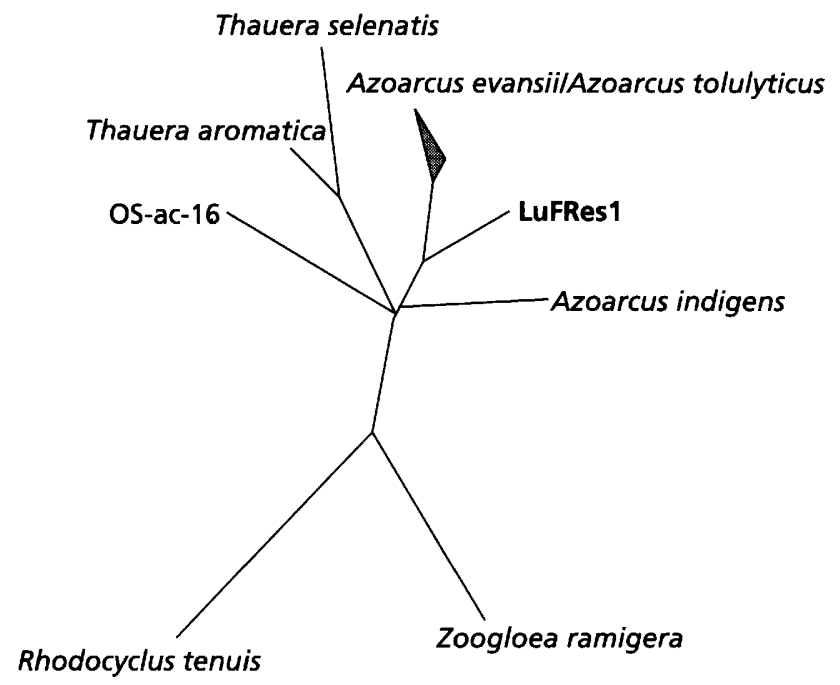

$10 \%$

Fig. 1. $16 \mathrm{~S}$ rRNA-based tree reflecting the relationships of strain LuFRes $1^{\top}$ and a selection of its closest relatives among members of the $\beta$-subclass of the Proteobacteria. Strain OS-ac-16 is a $\beta$ proteobacterium isolated from a hot spring microbial mat. The topology of the tree is based on the results of distance-matrix analysis. Only sequence positions which share identical residues among $50 \%$ of all available complete 165 rRNA sequences from the $\beta$-subclass Proteobacteria were included for tree construction. Multifurcations indicate that a common relative branching order was not supported by the results obtained performing different treeing methods. The bar indicates $10 \%$ estimated sequence divergence.

dismutase-positive. Poly-( $\beta$-hydroxy)butyrate is accumulated. Metabolism strictly oxidative, nitrate used as the only electron acceptor, which is quantitatively reduced to $\mathrm{N}_{2}$ gas. Nitrite accumulates intermediately, $\mathrm{N}_{2} \mathrm{O}$ was not detected. Sulfate, thiosulfate, sulfite, sulfur, trimethylamine $N$-oxide, DMSO, $\mathrm{Fe}(\mathrm{OH})_{3}, \mathrm{~K}_{3}\left[\mathrm{Fe}(\mathrm{CN})_{6}\right]$, or fumarate not reduced, oxygen not reduced, not even at low pressures in gradient cultures.

Acetate, propionate, butyrate, valerate, ethanol, propanol, lactate, pyruvate, fumarate, succinate, cyclohexanecarboxylate, phenol, resorcinol, benzoate, 3hydroxybenzoate, 4-hydroxybenzoate, phenylacetate, $p$-cresol, phenylalanine, tyrosine used as electron donors. No growth with $\mathrm{D}, \mathrm{L}-$ malate, adipate, $\mathrm{D}(+)$ xylose, $\mathrm{L}(-)$-arabinose, $\mathrm{D}(+)$-glucose, $\mathrm{D}(-)$-fructose, formate, 5-oxocaproate, pimelate, catechol, hydroquinone, 2-hydroxybenzoate, $o$-cresol, $m$-cresol. Growth only chemo-organoheterotrophic. No autotrophic growth with hydrogen or thiosulfate. Substrates completely oxidized to $\mathrm{CO}_{2}$. No nitrogenase activity but assimilatory utilization of nitrate. Doubling time of growth with resorcinol plus nitrate $4 \cdot 8-7 \cdot 4 \mathrm{~h}$. $\mathrm{pH}$ range $6 \cdot 5-8 \cdot 2$; optimum $\mathrm{pH} 7 \cdot 2$. Temperature range $20-32{ }^{\circ} \mathrm{C}$; optimum temperature $28^{\circ} \mathrm{C}$. Growth optimal in freshwater medium; enhanced salt concentrations impair growth. DNA $\mathrm{G}+\mathrm{C}$ ratio $66.5 \pm 0.5 \mathrm{~mol} \%$. Habitat is sewage sludge. The type strain is Azoarcus anaerobius LuFRes $1^{\mathrm{T}}$ (= DSM $12081^{\mathrm{T}}$ ).

\section{ACKNOWLEDGEMENTS}

This study was supported by a grant of the Deutsche Forschungsgemeinschaft, Bonn-Bad Godesberg, in its special research program on biochemistry of anaerobic bacteria. The authors thank Norbert Gorny for his initial work on characterization of this strain. The technical assistance of Ingrid Pomper is highly acknowledged.

\section{REFERENCES}

1. Anders, H. J., Kaetzke, A., Kaempfer, P., Ludwig, W. \& Fuchs, G. (1995). Taxonomic position of aromatic-degrading denitrifying pseudomonad strains K 172 and KB 740 and their description as new members of the genera Thauera, as Thauera aromatica sp. nov., and Azoarcus, as Azoarcus evansii sp. nov. Int J Syst Bacteriol 45, 327-333.

2. Fuchs, G., Mohamed, M., Altenschmidt, U., Koch, J., Lack, A., Brackmann, R., Lochmeyer, C. \& Oswald, B. (1994). Biochemistry of anaerobic biodegradation of aromatic compounds. In Biochemistry of Microbial Degradation, pp. 513-553. Edited by C. Ratledge. Dordrecht: Kluwer.

3. Gorny, N., Wahl, G., Brune, A. \& Schink, B. (1992). A strictly anaerobic nitrate-reducing bacterium growing with resorcinol and other aromatic compounds. Arch Microbiol 158, 48-53.

4. Hurek, T. \& Reinhold-Hurek, B. (1995). Identification of grass-associated and toluene-degrading diazotrophs, Azoarcus spp., by analyses of partial 16S ribosomal DNA sequences. Appl Environ Microbiol 61, 2257-2261.

5. Hurek, T., Burggraf, S., Woese, C. R. \& Reinhold-Hurek, B. (1993). 16S rRNA-targeted polymerase chain reaction and oligonucleotide hybridization to screen for Azoarcus spp., grass-associated diazotrophs. Appl Environ Microbiol 59, $3816-3824$

6. Kluge, C., Tschech, A. \& Fuchs, G. (1990). Anaerobic metabolism of resorcylic acids ( $m$-dihydroxybenzoic acids) and resorcinol (1,3-benzenediol) in a fermenting and in a denitrifying bacterium. Arch Microbiol 155, 68-74.

7. Ludwig, w. (1995). Sequence databases. In Molecular Microbial Ecology Manual, chapter 3.3.5, pp. 1-22. Edited by A. D. L. Akkermans. Dordrecht: Kluwer.

8. Schink, B., Brune, A. \& Schnell, S. (1992). Anaerobic degradation of aromatic compounds. In Microbial Degradation of Natural Products, pp. 219-242. Edited by G. Winkelmann. Weinheim: VCH.

9. Schink, B. \& Pfennig, N. (1982). Fermentation of trihydroxybenzenes by Pelobacter acidigallici gen. nov. sp. nov., a new strictly anaerobic non-sporeforming bacterium. Arch Microbiol 133, 195-201.

10. Springer, N., Ludwig, W., Drozanski, V., Amann, R. \& Schleifer, K. H. (1992). The phylogenetic status of Sarcobium lyticum, an obligate intracellular parasite of small amoebae. FEMS Microbiol Lett 96, 199-202.

11. Stackebrandt, E. \& Goebel, B. M. (1994). Taxonomic note: a place for DNA-DNA reassociation and 16S rRNA se- 
quence analysis in the present species definition in bacteriology. Int J Syst Bacteriol 44, 846-849.

12. Strunk, O. \& Ludwig, W. (1995). ARB- a software environment for sequence data. Department of Microbiology, University of Munich, Munich, Germany (e-mail arb@mikro.biologie.tu-muenchen.de).

13. Tschech, A. \& Schink, B. (1985). Fermentative degradation of resorcinol and resorcylic acids. Arch Microbiol 143, 52-59.

14. Wayne, L. G., Brenner, D. J., Colwell, R. R. \& 9 other authors (1987). International Committee on Systematic Bacteriology. Report of the ad hoc committee on reconciliation of approaches to bacterial systematics. Int J Syst Bacteriol 37, 463-464.

15. Widdel, F. \& Pfennig, N. (1981). Studies on dissimilatory sulfate-reducing bacteria that decompose fatty acids. I. Isolation of new sulfate-reducing bacteria enriched with acetate from saline environments. Description of Desulfobacter postgatei gen. nov., sp. nov. Arch Microbiol 129, 395-400.

16. Widdel, F., Kohring, G. W. \& Mayer, F. (1983). Studies on dissimilatory sulfate-reducing bacteria that decompose fatty acids. 3: Characterisation of the filamentous gliding Desulfonema limicola gen. nov. sp. nov., and Desulfonema magnum sp. nov. Arch Microbiol 134, 286-294.

17. Zhou, J., Fries, M. R., Chee-Sanford, J. C. \& Tiedje, J. M. (1995). Phylogenetic analyses of a new group of denitrifiers capable of anaerobic growth on toluene and description of Azoarcus tolulyticus sp. nov. Int J Syst Bacteriol 45, $500-506$. 